\title{
Bioprospecting and enzymatic potential of filamentous fungi from the Bela Vista Biological Refuge in Itaipu, Brazil
}

\author{
J.M. Corrêa ${ }^{1}$, S.S. de Moraes ${ }^{2}$, C. Henn ${ }^{3}$, M.K. Kadowaki ${ }^{1}$, \\ J.L. da C. Silva ${ }^{1}$, A. Maller ${ }^{1}$ and R. de C.G. Simão ${ }^{1}$ \\ ${ }^{1}$ Centro de Ciências Médicas e Farmacêuticas, Universidade Estadual do Oeste \\ do Paraná, Cascavel, PR, Brasil \\ ${ }^{2}$ Centro de Ciências Biológicas, Universidade Estadual do Oeste do Paraná, \\ Cascavel, PR, Brasil \\ ${ }^{3}$ Itaipu Binacional, Foz do Iguaçu, PR, Brasil \\ Corresponding author: J.M. Corrêa \\ E-mail: julianacb6974@ hotmail.com
}

Genet. Mol. Res. 18 (4): gmr18377

Received May 22, 2019

Accepted November 05, 2019

Published November 30, 2019

DOI http://dx.doi.org/10.4238/gmr18377

\begin{abstract}
Disordered anthropic action causes relevant impacts on different ecosystems. This may endanger key species and the compounds they produce, which have potential for commercial development. We collected environmental samples from the Bela Vista Biological Refuge, belonging to ITAIPU/Brazil, over a period of three years. A total of 181 fungal species were isolated and evaluated for cellulases and xylanases, $74 \%$ of which were classified as good enzymatic producers, with a production of up to $50 \mathrm{U} / \mathrm{mL}$ of xylanase and $7 \mathrm{U} / \mathrm{mL}$ for cellulase. A total of 34 isolates were selected and identified by amplification of internal transcribed spacer regions and then analyzed in BLASTn with 89-99\% similarity/identity with others deposited in GenBank; the genera found were Aspergillus, Penicillium, Chaetomium, Clonostachys, Fusarium, Hypocrea, Paecilomyces, Thermoascus, Thermomyces, and Trichoderma. The enzymatic data reveals details of the roles of this biological community. The ability of these fungal species to utilize plant cell wall compounds discovered based on bioprospecting analysis of this biome is a pioneering study for this purpose in this region and points out important microorganisms that have potential for enzymatic production in biological biomass depolymerization, resulting in biotechnologically useful products.
\end{abstract}


Key words: Biomass depolymerization; Internal Transcribed Spacer; Xylanolytic enzymes

\section{INTRODUCTION}

Fungi are considered key organisms in environments of high diversity as they are osmotrophic, feeding by secreting macromolecules into the extracellular environment, resulting in metabolites that are moved into the cell, thus presenting a great ability to adapt to various environmental conditions (Richards and Talbot, 2013). The global increase in energy consumption worldwide and the actual estimated depletion of fossil fuel reserves in the near future, coupled with the depletion of ecosystems by anthropogenic action, has lead to a search for knowledge of new resources for alternative fuels that target different biotechnological applications, such as enzymatic hydrolysis by environmental fungi (Arora et al., 2015). Some fungi, such as Pseudocercospora spp., have been isolated from various different biomes, such as the semi-arid cerrado (Furlanetto and Dianese, 1999) and the Atlantic forest (Parreira et al., 2014). Although this genus has a wide distribution, it is quite genetically diverse, particularly in tropical and subtropical environments (Silva et al., 2016).

Phylogenetic analysis through the production of phylogenetic trees allows us to know the similarity of a given population of individuals and their possible ancestral relationships (Ney and Kumar, 2000; Felsenstein, 2004; Hall, 2011), which is currently being constructed by molecular data analysis, DNA sequences, or proteins. Environmental fungal diversity patterns are being more commonly studied and described using nucleotide sequences generated by next generation DNA sequencing, which produces a large number of extensive sequences that can be identified by automated bioinformatics tools (Caporaso et al., 2010).

In bioinformatics analyses, the nucleotide sequences are filtered and processed, and the Operational Taxonomic Units (OTUs) are collected using reference-based approaches. The taxonomy is attributed to representative OTU sequences and an array is created when there is an abundance of OTUs. In the sequence, OTU sequences are grouped together, and a taxonomy is assigned to the clusters obtained (Lindahl et al., 2013; Hart et al., 2015). The taxonomy attribution is particularly sensitive to the qualitative properties of the reference sequence affecting the amplitude of taxa, with sufficient information for inferences regarding intra- and inter-specific genetic variations.

The purpose of this study was to isolate fungi from various sources of native forest biomass for their application in future biotechnological processes. The microorganisms were isolated by conventional microbiological methods and submitted to molecular identification, such as amplification of ITS1-4/rRNA genes by PCR, followed by DNA sequencing by the Sanger et al. (1977) method.

\section{MATERIAL AND METHODS}

\section{Study area, collection and sample processing}

The fungi species used in this study are data from a network project called Sisbiota, approved by the National Council for Scientific and Technological Development (CNPQ), 563260/2010-6-Brazil. Samples of litterfall, soil and water were collected on an Atlantic 
Forest biome trail, located at the Bela Vista Biological Refuge, Foz do Iguaçu, Paraná, Brazil, at the coordinates $25^{\circ} 26^{\prime} 41.90^{\prime \prime} \mathrm{S}, 54^{\circ} 33^{\prime} 06.09^{\prime \prime} \mathrm{W}$, with an elevation of $750 \mathrm{~m}$ (Figure 1). Litterfall samples were collected and deposited in plastic bags and water in sterile glass bottles, later taken to the laboratory for separation (leaves, stems, seeds and root) and cleaning to reduce bacterial load by contact with a 5\% hypochlorite solution followed by distilled water. These components were then placed on a Petri dish containing potato dextrose agar (BDA) plus chloramphenicol $(50 \mathrm{mg} / \mathrm{L})$ to prevent bacterial and yeast growth. Later the plates with samples in duplicates were divided at temperatures of 28 and $46^{\circ} \mathrm{C}$ (microbiological greenhouse) for selection of mesophilic and thermophilic fungi.

The isolation of fungi from soil and water samples was performed by surface spreading directly on BDA solid medium according to the methodology described by Warcup (1950). All incubated samples were monitored daily for mycelial growth until obtaining isolated colonies. All strains isolated from these samples were transferred to glass tubes containing slanted BDA solid medium and refrigerated at $10^{\circ} \mathrm{C}$.

\section{Determination of enzymatic index values}

To examine the enzyme production capacity of the xylanolytic complex, the isolated fungi were inoculated at the center of a Petri dish containing modified M5 solid medium $(0.05 \%$ peptone, $0.1 \%$ yeast extract, $0.5 \% \mathrm{NaCl}, 0.1 \% \mathrm{CaCl}, 0.5 \%$ Xylan, $1.5 \%$ Agar), supplemented with $1 \%(\mathrm{w} / \mathrm{v})$ beechwood xylan for xylanase activity analysis and cellulase in a Luria-Bertani LB medium plus $1 \%$ carboxymethylcellulose (w/v).

The fungi were grown for $24-72 \mathrm{~h}$ at 28 or $46^{\circ} \mathrm{C}$ and then incubated at $50^{\circ} \mathrm{C}$ for 16 $\mathrm{h}$. The development of a halo was performed with $0.1 \%$ Congo red solution in $0.1 \mathrm{M}$ Tris buffer, $\mathrm{pH}$ 8, for $30 \mathrm{~min}$, washed with $1 \mathrm{M}$ saline solution for $15 \mathrm{~min}$ (Neiroti and Azevedo 1988; Ruegger and Tauk-Tornisielo, 2004), allowing the visualization of hydrolysis halos of the substrate, and the diameter of the halo was measured with the aid of a pachymeter.

\section{Enzymatic determination for cellulase and xylanase}

Filamentous fungi were incubated with shaking at their respective isolation temperatures in Czapeck liquid mineral medium (Wiseman, 1975), the inoculum was prepared for a suspension of $10^{5}$ spores / $\mathrm{mL}$ in $25 \mathrm{~mL}$ of medium supplemented with $1 \%$ glucose. The cultures were filtered and stored in sterile flasks with the aid of a Büchner funnel vacuum pump to obtain the crude enzyme extract.

Crude extracts were quantified for xylanase and cellulase enzymatic activities using standard beechwood xylane and carboxymethylcellulose (CMCase) substrates, respectively. Both enzymes were quantified by the formation of reducing sugars in the reaction medium containing $1 \%$ substrate in $\mathrm{pH} 6$ sodium citrate buffer according to the 3,5-dinitrosalicylic acid - DNS method (Miller 1959). For the determination of the enzymatic activity, the reaction was carried out in a solution of $500 \mu \mathrm{L}$ of enzyme from the crude extract and 500 $\mu \mathrm{L}$ of the substrate (sodium carboxymethylcellulose or beechwood xylan), and then incubated at $40^{\circ} \mathrm{C}$ for $30 \mathrm{~min}$. Successive aliquots were taken $(125 \mu \mathrm{L})$ at $10 \mathrm{~min}$ intervals and added to tubes containing $125 \mu \mathrm{L}$ of the DNS solution. The tubes were then heated for 5 min in a water bath, added $1 \mathrm{~mL}$ of distilled water added, then read in a spectrophotometer at $540 \mathrm{~nm}$, where the values obtained were compared to a standard 
glucose curve (for cellulase calculation) or xylose curve (for xylanase determination). The enzyme activity unit in both enzymes was defined as the concentration of micromoles of reducing sugars (glucose or xylose) released per $1 \mathrm{~mL}$ in 1 min reaction $(\mathrm{U} \mathrm{mL}-1)$ under the assay conditions.

\section{Culture conditions and extraction of genomic DNA}

The fungi were grown under suitable conditions in test tubes with BDA medium under defined conditions in isolation and then inoculated into $250 \mathrm{~mL}$ flask flasks in cultures containing $25 \mathrm{~mL}$ Czapek liquid medium (Wiseman 1975) supplemented with $1 \%$ glucose for 24-48 $\mathrm{h}$ or until obtaining apparent mycelial mass; the cultures were then vacuum-filtered for extraction of the genomic DNA. The mycelial mass obtained from the cultures was transferred to $1.5 \mathrm{~mL}$ conical tubes, an estimated amount of $200 \mathrm{uL}$ or $0.2 \mathrm{~g}$ with $600 \mathrm{uL}$ of the extraction solution (EDTA $0.05 \mathrm{M} ; 1 \%$ SDS) heated at $65^{\circ} \mathrm{C}$ for $20 \mathrm{~min}$. They were the centrifuged at 12,000 rpm for $10 \mathrm{~min}$ at room temperature. The upper phase was transferred to a new tube and treated with $50 \mu \mathrm{L}$ of RNase $20 \mathrm{mg} / \mathrm{mL}$ for $60 \mathrm{~min}$ at $37^{\circ} \mathrm{C}$. Then $300 \mu \mathrm{L}$ of chloroform: isoamyl alcohol (24:1) was added and mixed by manual inversion, with centrifugation at $12,000 \mathrm{rpm}$ for $10 \mathrm{~min}$ at room temperature. The upper layer was recovered and precipitated with $40 \mu \mathrm{L} 5 \mathrm{M}$ potassium acetate, $\mathrm{pH} 4.8$, and after mixing, packed on ice for $30 \mathrm{~min}$. The sample was centrifuged again at 12,000 rpm for 10 min at $4{ }^{\circ} \mathrm{C}$. The supernatant was transferred to a new tube and precipitated with $1 \mathrm{~mL}$ of absolute ethanol, followed by centrifugation and re-insertion of $70 \%$ ethanol with centrifugation at $1,2000 \mathrm{rpm}$ at $4^{\circ} \mathrm{C}$ for $5 \mathrm{~min}$.

Again, absolute ethanol was added, followed by $70 \%$ ethanol with the abovementioned centrifugation between one and the other step. Subsequently, the ethanol was discarded, and the tube was dried at room temperature. Finally, the DNA precipitate was resuspended in $50 \mu \mathrm{L}$ TE/Rnase. The theoretical extraction yield was obtained in a spectrophotometer at $260 \mathrm{~nm}$.

\section{Amplification of rDNA ITS 1 and 4 regions}

For the identification of the fungal isolates, the ITS 1 and 4 regions of the ribosomal DNA (rDNA) were analyzed (White et al., 1990). The PCR reaction comprised a mixture of genomic DNA [100-200 ng]; Promega ${ }^{\circledR}$ buffer [1x]; $\mathrm{MgCl} 2$ [1.5 mM]; ITS 1 and 4 primer $[1 \mathrm{mM}] ;$ dNTP [2.5 mM]; Promega ${ }^{\circledR}$ Taq DNA polymerase [0.5 U], and distilled water to a final volume of $25 \mu \mathrm{L}$.

The amplification of the genomic DNA samples was performed in a thermocycler starting at $95^{\circ} \mathrm{C}$ for $2 \mathrm{~min}$, followed by 35 cycles of $94^{\circ} \mathrm{C}$ for $45 \mathrm{~s}$ of denaturation; $50-60^{\circ} \mathrm{C}$ for $1 \mathrm{~min}$ of annealing; and $72^{\circ} \mathrm{C}$ for $45 \mathrm{~s}$, with inactivation at $72^{\circ} \mathrm{C}$ for $5 \mathrm{~min}$. Visualization of genomic DNA and PCR-amplified fragments were on agarose gel in 1X TAE buffer, stained with ethidium bromide. The amplified DNA fragments were purified using the Purelink PCF Purification Kit (Invitrogen ${ }^{\circledR}$ ) and prepared for sequencing with the Big Dye Terminator 3.1 Kit (Applied Biosystems ${ }^{\circledR}$ ). Sequencing was performed by the DNA Sequencing Service of the Institute of Chemistry of the University of São Paulo, SP, Brazil. 


\section{Analysis of gene sequences}

Genetic sequences from the amplification of the ITS1-5.8S-ITS4 ribosomal DNA regions were analyzed in the NCBI using the BLASTn tool, in order to identify the strains at the genus and species levels.

\section{Phylogenetic trees}

The DNA sequences were appropriately aligned in the MAFFT (Multiple Alignment using Fast Fourier Transform) program. Following that, the phylogenetic trees were estimated by the Neighbor Joining method of the Mega 7.0 program.

\section{RESULTS}

\section{Study area, collection and sample processing}

The Atlantic Forest biome, located at the Bela Vista Biological Refuge, Foz do Iguaçu, Paraná, Brazil, located at coordinates $25^{\circ} 26^{\prime} 41.90^{\prime \prime}$ S, 54 $33^{\circ} 06.09^{\prime \prime}$ W, with an elevation of $750 \mathrm{~m}$ (Figure 1). It is a forest remnant that has been extensively damaged by anthropic action. The loss of species is advancing year after year (Valencia and Chambergo 2013). This study included the isolation of filamentous fungal species with potential of applicability in biotechnological processes on plant biomass through the investigation of xylanolytic complex enzymes. In the period from 2011 to 2013, four collections were carried out in different weather stations in this Brazilian biome, which allowed the obtaining of 181 isolates. The viable fungal spores that gave rise to the isolates came from different environmental samples of this biome (Figure 2), the stem and soil standing out, with 26 and $27 \%$, respectively.

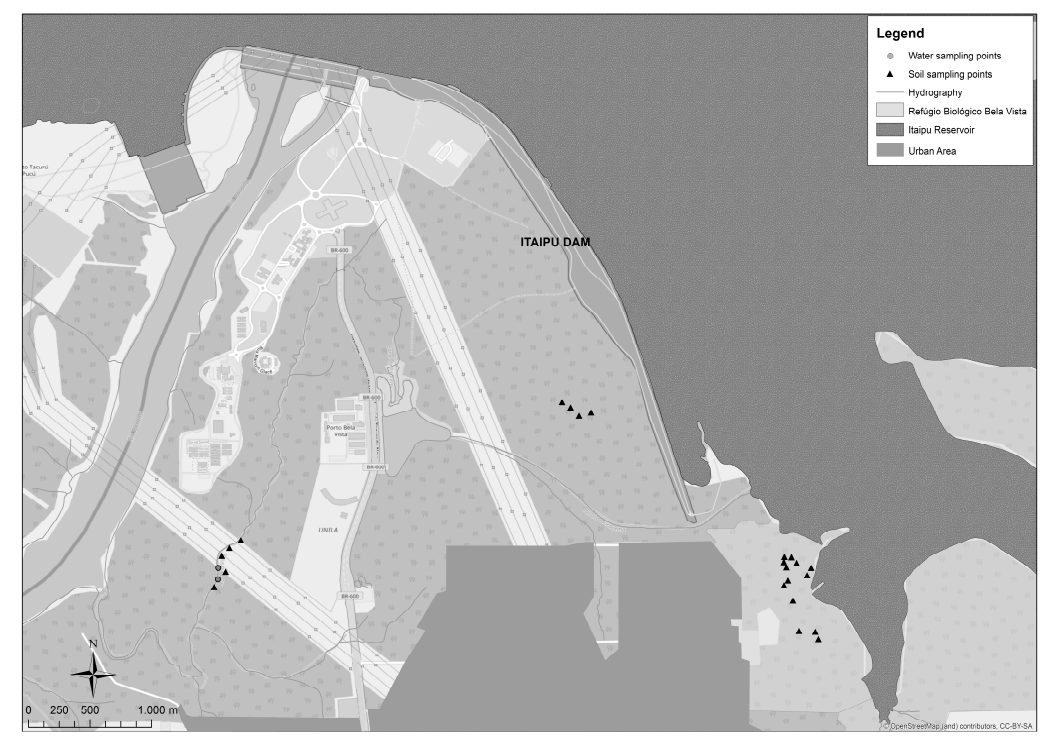

Figure 1: Origin of the isolation of filamentous fungi by type of environmental sample. 


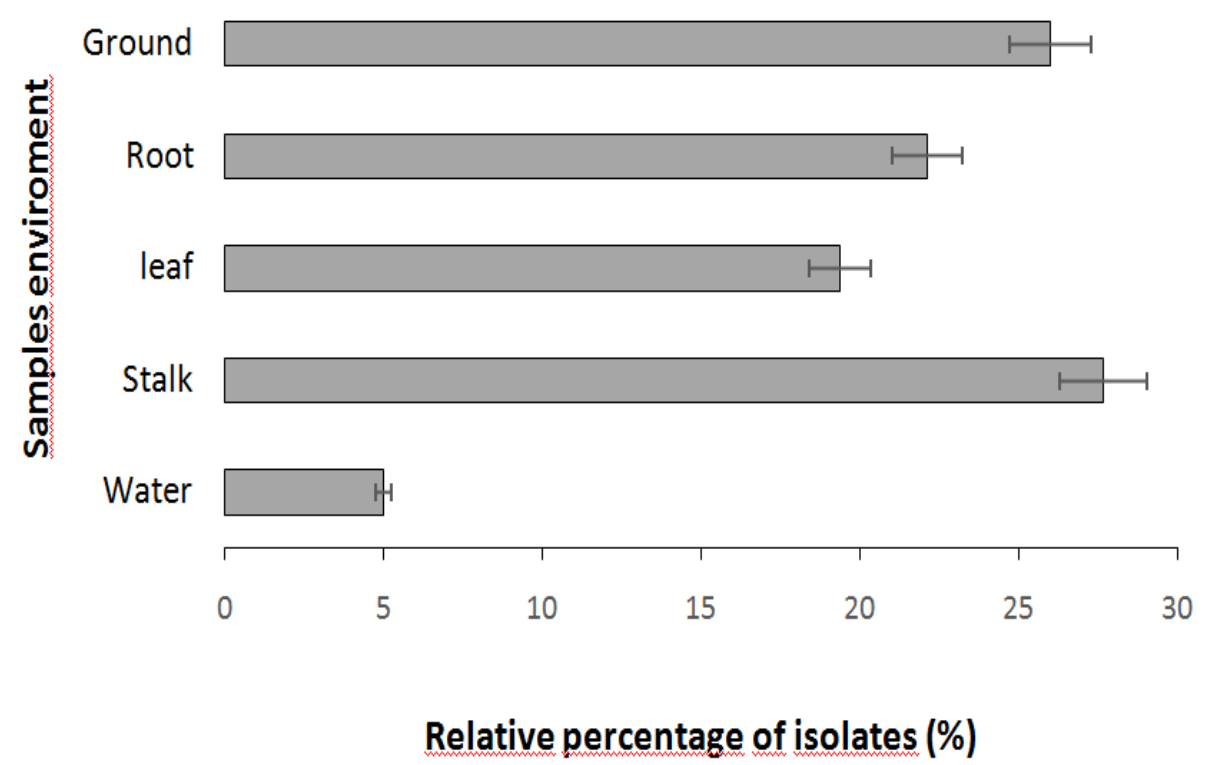

Figure 2. Origin of the isolation of filamentous fungi by type of environmental sample.

Species isolation was variable according to the collection season, with 64 species in winter, 37 species in spring, 48 species in autumn, and 32 species in summer (unpublished data). The enzymatic production capacity (xylanase and cellulase) was verified by means of individual tests of the isolates in a solid medium with halo hydrolysis development, characterized by a clear zone around the colony (Figure 3B), which allowed the determination of the enzymatic qualitative index of the strains. The occurrence of the two enzymes were observed in 134 isolates and in 47 the complete absence of activity due to the absence of a halo in the two tested situations (figure 3A). The enzymatic quantification in substrates for determination of the cellulase and xylanase activities of the fungi that presented the largest halos in the qualitative test are shown in Figures 4A, 4B and 4C. In general, xylanase activity was higher in all 34 species when cellulase activities that were below $7 \mathrm{U} / \mathrm{mL}$ were compared.

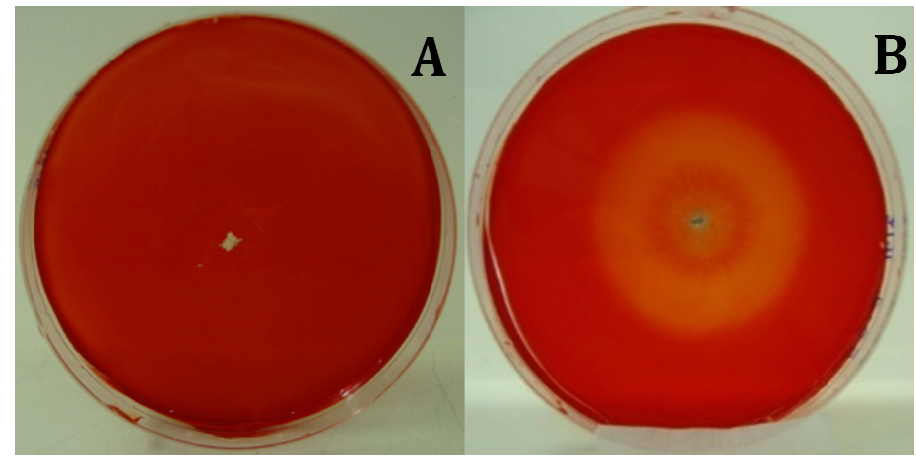

Figure 3. Enzymatic index test. Legend: $A=$ Negative test; $B=$ Positive test. 


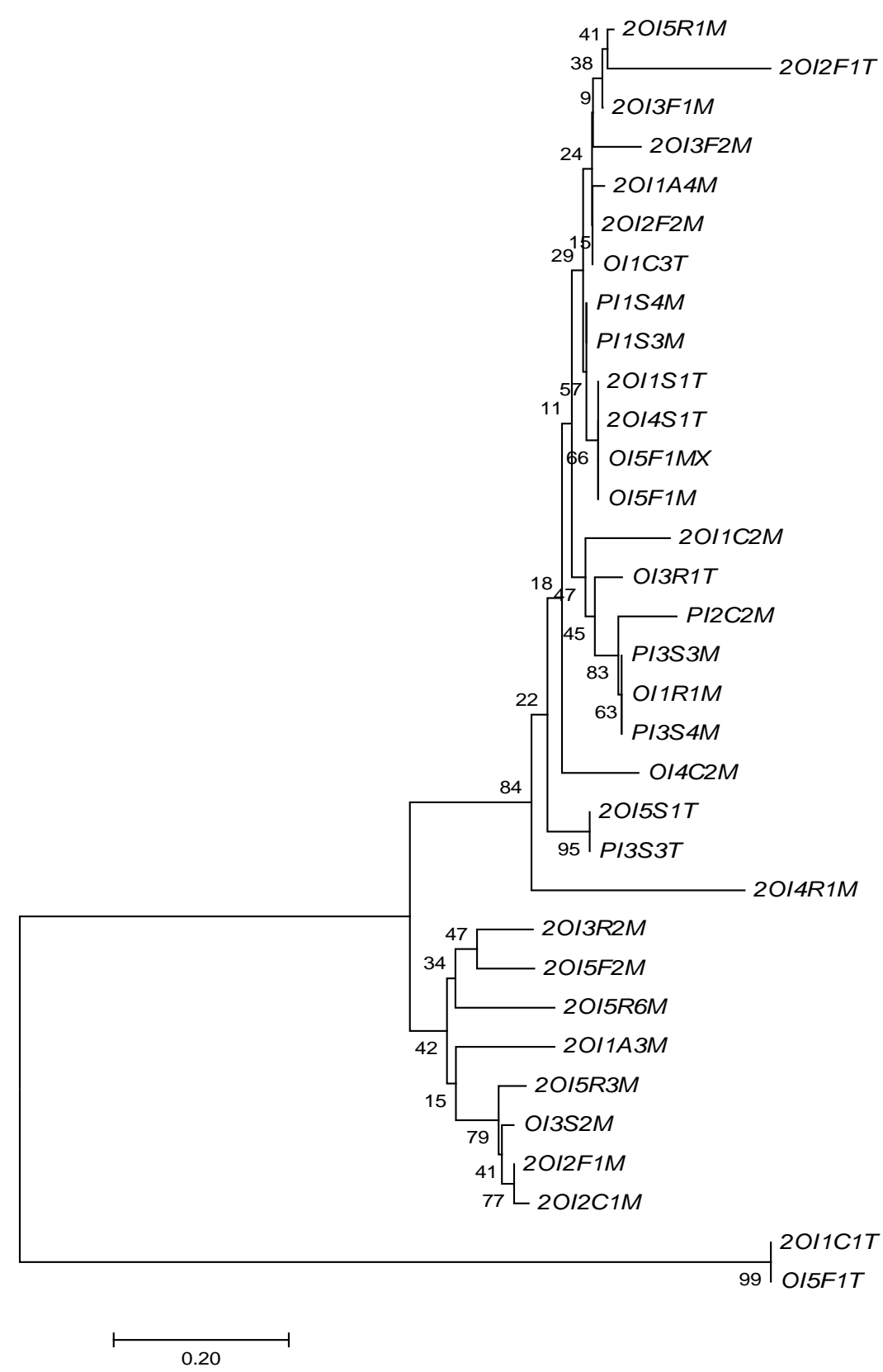

Figure 4. List of evolutionary rates of the fungal community belonging to the Atlantic Forest Biome of the Bela Vista Biological Refuge, Paraná, Brazil.

A. fumigatus KM382061 exhibited $50 \mathrm{U} \cdot \mathrm{mL}^{-1}$ of xylanase (Fig. 5A). P. crysogenum KY549809 62 U.mL ${ }^{-1}$ showed a higher xylanase activity than Trichoderma virens KM516021 with 27 U.mL ${ }^{-1}$ (Fig 5B). 

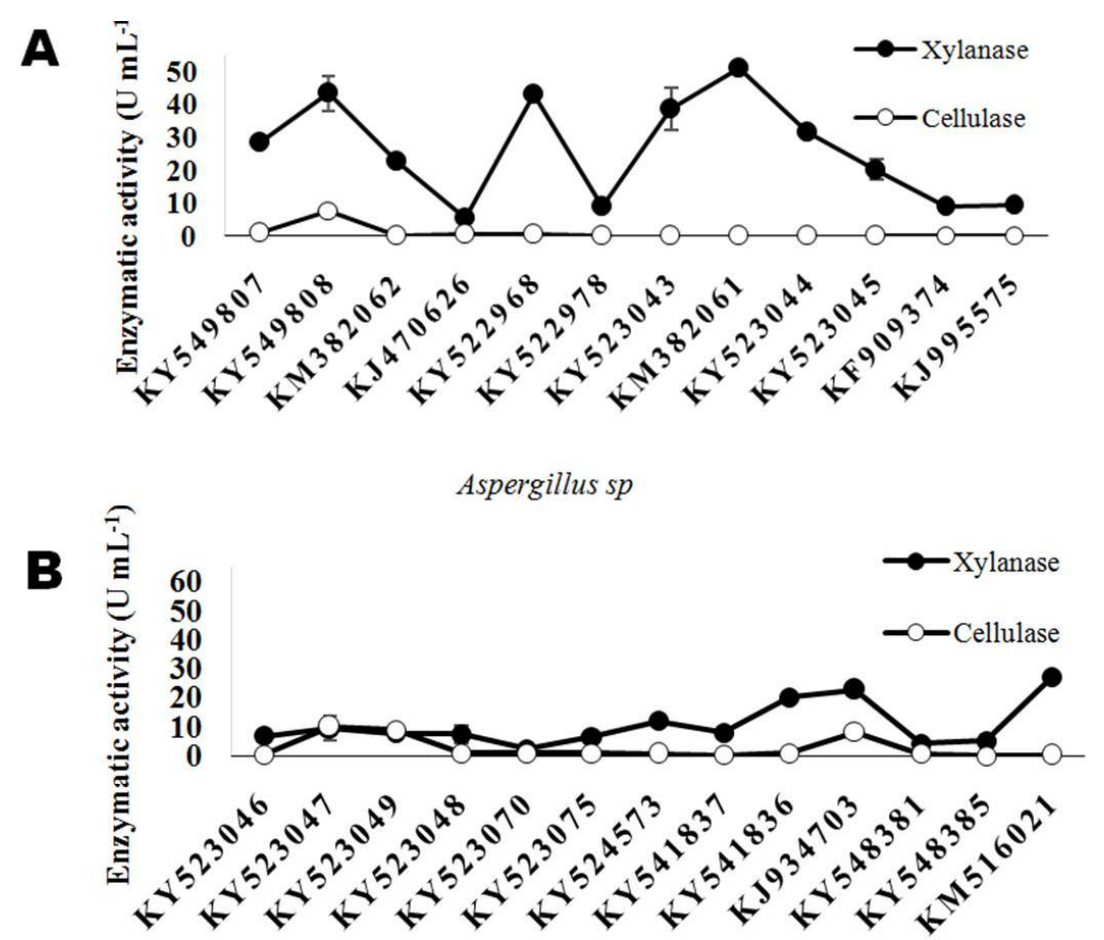

Penicillium $s p$

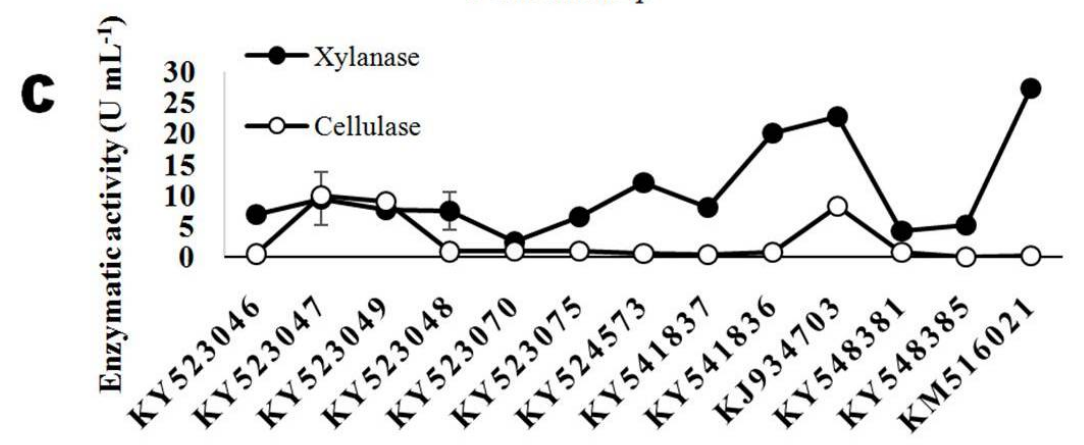

Fungus isolated

Figure 5: Quantitative enzymatic determination for xylanase and cellulase of Atlantic forest biome isolates. AIsolated fungal group Aspergillus sp. B- Isolates fungal group Penicillium sp. C- Other isolated group.

\section{Culture conditions and extraction of genomic DNA}

Among the isolated species, 34 were selected for molecular identification, as they presented desirable colony and hydrolytic capacity characteristics. In these isolates, genomic DNA extraction and subsequent amplification at temperatures of $50-60^{\circ} \mathrm{C}$ with ribosomal ITS 1 and 4 primers were performed, and amplification resulted in inserts of 520- 
1,007 bp (Table 1). The sequences were purified and prepared for sequencing, which generated identified 13 fungi of the genus Aspergillus, 9 Penicillium, 3 Trichoderma and Thermoascus, 2 Fusarium, and 4 of miscellaneous genera (Table 1). When analyzing the sequences of the isolates in NCBI by means of BLASTn, the similarity was 88-99\%. All study sequences were deposited in the same database under individualized codes (Table 1).

\section{Table 1: Data on the identified fungi of the Atlantic Forest Biome.}

\begin{tabular}{|c|c|c|c|c|c|c|c|c|c|c|c|}
\hline \multirow{3}{*}{$\begin{array}{l}\text { Acess } \\
\text { NCBI }\end{array}$} & \multirow[b]{3}{*}{ Identification of isolate } & \multirow{3}{*}{$\begin{array}{c}\text { Isolated } \\
\text { source } \\
\end{array}$} & \multirow[b]{3}{*}{ Growth condition } & \multirow{3}{*}{$\begin{array}{l}\text { Size } \\
(\mathbf{p b})\end{array}$} & \multirow{3}{*}{$\begin{array}{c}\text { Homology } \\
(\%)\end{array}$} & \multicolumn{6}{|c|}{ Enzymatic determination } \\
\hline & & & & & & \multicolumn{3}{|c|}{ Xylanase } & \multicolumn{3}{|c|}{$\begin{array}{l}\text { Cellulase } \\
\end{array}$} \\
\hline & & & & & & ØC & ØH & Ie & $\varnothing \mathrm{C}$ & $\varnothing \mathrm{H}$ & Ie \\
\hline KY549807 & Aspegillusflavus & caule & mesophile & 570 & 99 & 3,9 & 4,95 & 1,27 & 2,75 & 3,4 & 1,24 \\
\hline KY549808 & Aspegillusflavus & ground & mesophile & 567 & 99 & 1,95 & 4,5 & 2,31 & 2,8 & 4 & 1,43 \\
\hline KM382062 & Aspergillusaculeatus & stalk & mesophile & 466 & 99 & 1,15 & 1,9 & 1,65 & 1,35 & 2,75 & 2,04 \\
\hline KJ470626 & Aspergillusflavus & root & mesophile & 529 & 98 & 2,4 & 4,55 & 1,9 & 1,2 & 2,75 & 2,29 \\
\hline KY522968 & Aspergillusfumigatus & stalk & termophilic & 570 & 99 & 0,7 & - & - & 1 & 3 & 3 \\
\hline KY522978 & Aspergillusfumigatus & ground & termophilic & 670 & 99 & 2,6 & 4 & 1,53 & 4 & 4,5 & 1,05 \\
\hline KY523043 & Aspergillusfumigatus & ground & termophilic & 573 & 98 & 2 & 5 & 2,5 & 2 & 3 & 1,5 \\
\hline KM382061 & Aspergillusfumigatus & leaf & mesophile & 521 & 98 & 2,95 & 3,2 & 1,1 & 1,1 & 1,3 & 1,18 \\
\hline KY523044 & Aspergillusfumigatus & leaf & termophilic & 840 & 91 & 0,35 & 1,3 & 3,75 & 1,75 & 2,15 & 1,23 \\
\hline KY523045 & Aspergillusfumigatus & ground & mesophile & 978 & 89 & 1,6 & 3,45 & 2,16 & 1,85 & - & - \\
\hline KF909374 & Aspergillusniger & root & termophilic & 533 & 99 & 1,25 & 2,45 & 1,96 & 1,3 & 2,3 & 1,77 \\
\hline KJ995575 & Aspergillustamarii & ground & mesophile & 543 & 98 & 2,75 & 3,8 & 1,38 & 2,1 & 3,5 & 1,67 \\
\hline KY523046 & Chaetomiumglobosum & water & mesophile & 547 & 99 & 2,7 & 3,5 & 1,29 & 2 & - & - \\
\hline KY523047 & Clonostachysrosea & water & mesophile & 748 & 98 & 2,6 & 3,9 & 1,5 & 0,8 & 1,9 & 2,37 \\
\hline KY523049 & Fusariumdecemcellulare & root & mesophile & 546 & 98 & 1,9 & 3,6 & 1,89 & 1,9 & - & - \\
\hline KY523048 & Fusariumequiseti & leaf & mesophile & 520 & 98 & 2,2 & 4,4 & 2 & 4,3 & 4,5 & 1,05 \\
\hline KY523070 & Hypocrealixii & leaf & mesophile & 574 & 96 & 3,1 & - & - & 1,85 & 3,75 & 2,03 \\
\hline KY523075 & Paecilomycessp & stalk & mesophile & 534 & 96 & 5,6 & - & - & 2,8 & 3,1 & 1,1 \\
\hline KU560628 & Penicilliumbrefeldianum & ground & mesophile & 530 & 99 & 2,95 & 3,55 & 1,2 & 2,45 & - & - \\
\hline KY524459 & Penicilliumchrysogenum & leaf & termophilic & 565 & 88 & 3,4 & 6,4 & 1,88 & 0,9 & 1,5 & 1,66 \\
\hline KY549809 & Penicilliumchrysogenum & leaf & mesophile & 683 & 97 & 2 & 4,6 & 2,3 & 2 & 6,1 & 3,05 \\
\hline KY524484 & Penicilliumchrysogenum & root & mesophile & 635 & 90 & 3,8 & 4,6 & 1,21 & 2,2 & - & - \\
\hline KY524460 & Penicilliumchrysogenum & leaf & mesophile & 760 & 98 & 3,4 & 3,7 & 1,08 & 2,5 & - & - \\
\hline KY524485 & Penicilliumcoтmune & water & mesophile & 559 & 99 & 2,2 & - & - & 0,9 & 2,2 & 2,44 \\
\hline KY549810 & Penicilliumcommune & leaf & mesophile & 1007 & 97 & 3,1 & 5,5 & 1,77 & 2,5 & 2,6 & 1,04 \\
\hline KY524487 & Penicilliumcommune & root & mesophile & 577 & 88 & 5,8 & 6,4 & 1,1 & 3,3 & - & - \\
\hline KM065878 & Penicilliumcrustosum & stalk & termophilic & 543 & 98 & 2,25 & 4,35 & 1,93 & 0,45 & 0,65 & 1,44 \\
\hline KY524573 & Purpureocilliumlilacinum & root & mesophile & 563 & 98 & 1,9 & 2,6 & 1,36 & 1,4 & 1,9 & 1,35 \\
\hline KY541837 & Thermoascusaurantiacus & ground & termophilic & 726 & 99 & 1,5 & 4 & 2,66 & - & - & - \\
\hline KY541836 & Thermoascusaurantiacus & ground & termophilic & 768 & 99 & 6,9 & 7 & 1,01 & 6,1 & 6,3 & 1,01 \\
\hline KJ934703 & Thermomyceslanuginosus & leaf & mesophile & 563 & 99 & 2,95 & 3,2 & 1,1 & 1,1 & 1,3 & 1,18 \\
\hline KY548381 & Trichodermaharzianum & stalk & mesophile & 599 & 99 & 3 & 4 & 1,33 & 3,1 & 5,8 & 1,87 \\
\hline KY548385 & Trichodermalongibrachiatum & root & mesophile & 613 & 98 & 1,8 & 2,9 & 1,61 & 3,9 & 4,7 & 1,2 \\
\hline KM516021 & Trichodermavirens & ground & mesophile & 559 & 98 & 3,6 & 3,8 & 1,05 & 2,6 & - & - \\
\hline
\end{tabular}

Legend: $\varnothing \mathrm{D}=$ Colony diameter (centimeters); $\varnothing \mathrm{H}=$ Diameter of the halo (centimeters); Ie = Enzymatic index result of the ratio between $\varnothing \mathrm{D} / \varnothing \mathrm{H} ;(-)=$ Activity not detected based on absence of a halo.

\section{Analysis of gene sequences}

The sequences were submitted to a phylogenetic analysis to examine evolutionary history by inference using the Neighbor-Joining method (Saitou and Nei, 1987). The ideal tree with the sum of the branch length $=3.00864461$ is shown in Figure 4. The percentage of replicate trees in which the associated taxa grouped in the bootstrap test (500 replicates) is shown next to the branches (Felsenstein, 1985). The tree is drawn to scale, with branching lengths in the same units as those of the evolutionary distances used to infer the phylogenetic tree. The evolutionary distances were calculated using the Poisson correction method (Zuckerkandl and Pauling, 1965) and are in units of the number of amino acid substitutions per site. The analysis involved 34 amino acid sequences. The coding data were translated assuming a standard genetic code table. All positions with gaps and missing data 
were deleted. There were 74 positions in the final data set. Evolutionary analyses were performed on MEGA ${ }^{\circledR} 7.0$ (Kumar et al., 2016).

\section{DISCUSSION}

We found various fungi with relevant enzymatic production indices for xylanase and cellulase enzymes. The review of Valencia and Chambergo (2013) includes a systematic and organized survey of studies reporting the biodiversity of Brazil; the native fungi obtained through collections from different regions of the country showed important characteristics for efficient hydrolysis of biomass with potential biotechnological applications.

The isolation of strains with the purpose of exploration of the production of composites was developed by Celestino et al. (2014). They were able to isolate 50 species of fungi in the Amazon capable of producing pigments. Additionally, with different procedures for growth, with alterations in the culture medium, it was possible to produce a large number of natural pigments. As used in our project, Pandey et al. (2003) used the ITS technique to identify the endophytic fungi of trees in India, which allowed the identification of various tropical species that cause infection in the leaves and the establishment of a correlation with the genetic variation between the isolates.

The 34 fungi we identified showed considerable diversity, grouping in several clades. The identification by analysis of the greater dominance of Aspergillus and Penicillium species was made possible by the analysis of a repeated unit of ribosomal DNA, which is a useful way of examining polymorphism due to the juxtaposition of conserved and variable regions (Bruns et al., 1991). In phylogeny, these species present several clades, suggesting considerable intra-species variability. The amplification of the rRNA/ITS region as a tool for molecular identification of fungal species from various sources has been applied in regions with high biological diversity and is a useful tool for analysis of phylogenetic evolution (Xu et al., 2007).

From this perspective, some of these isolates reported have already been studied in the study of Andrades et al. (2016), who investigated the influence of alternative carbon sources as inducers of $\beta$-galactosidase and fructofuranosidase by filamentous fungi Aspergillus aculeatus KM382062, Aspergillus fumigatus KY522978 and Trichoderma longibrachiatum KY548385. The highest levels of intracellular $\beta$-galactosidase activity were obtained using orange peel residues $(56.31 \mathrm{U} / \mathrm{mL})$ with A. aculeatus, A. fumigatus $(17.26 \mathrm{U} / \mathrm{mL})$ and $T$. longibrachiatum $(17.53 \mathrm{U} / \mathrm{mL})$. The most effective activity of intracellular $\beta$-fructofuranosidase was obtained by A. aculeatus using trub (409.46 U / mL), showing that these agroindustrial substrates and fungi are excellent producers.

Another study using related isolates was conducted by Corrêa et al. (2016); Thermomyces lanuginosus KJ934703 exhibited high production of Beta-xylosidase, reaching production levels in corn straw of $1003 \mathrm{U} / \mathrm{mL}$. Farnsworth et al. (2015) demonstrated the need and difficulty to determine the value of biodiversity. They argue that this must be performed through an objective method, which can be achieved by a quantification of the relationship between the ecosystem and the services they can provide, achieving a biodiversity-function relationship. The diversity and the enzyme activities of the fungi that we found has potential for future exploration in biotechnology. 


\section{CONCLUSIONS}

The analysis of the biological diversity of our study area showed a richness of species that have potential for hydrolysis of plant biomass. The fungi that we identified will serve as a basis for biotechnological applications and increase knowledge regarding the filamentous fungi of a conservation area with remnants of the Atlantic Forest biome.

\section{ACKNOWLEDGMENTS}

We thank the Coordination for the Improvement of Higher Education Personnel CAPES for granting a scholarship. We thank ITAIPU for support and for allowing us to collect sample in the refuge.

\section{CONFLICTS OF INTEREST}

The authors declare no conflict of interest.

\section{REFERENCES}

Andrades D de, Oriente A, Henn C, et al. (2016). Improved production of $\beta$-galactosidase and $\beta$-fructofuranosidase by fungi using alternative carbon sources. Sci. Res. Essays. 10: 236-242. doi: 10.5897/sre2015.6065.

Arora R, Behera S and Kumar S (2015). Bioprospecting thermophilic/thermotolerant microbes for production of lignocellulosic ethanol: A future perspective. Annu. Rev. Ecol. Evol. Syst. 51: 699-717. doi: 10.1016/j.rser.2015.06.050.

Bruns TD, White TJ and Taylor JW (1991). Fungal Molecular Systematics. Annu. Rev. Ecol. Evol. Syst. 22: 525-564.

Caporaso JG, Lauber CL, Walters WA, et al. (2010). Global patterns of 16S rRNA diversity at a depth of millions of sequences per sample. PNAS. 108: 4516-4522. doi: 10.1073/pnas.1000080107/ /DCSupplemental.www.pnas.org/cgi/doi/10.1073/pnas.1000080107.

Celestino R, Ennes L, Carvalho D, et al. (2014). Bioprospecting of Amazon soil fungi with the potential for pigment production. Process Biochem. 49: 569-575. doi: 10.1016/j.procbio.2014.01.018.

Corrêa JM, Christi D, Torre CL Della, et al. (2016). High levels of $\beta$-xylosidase in Thermomyces lanuginosus : potential use for saccharification. Brazil. J. Microbiology. 47: 680-690. doi: 10.1016/j.bjm.2016.04.028.

Farnsworth KD, Adenuga AH and de Groot RS (2015). The complexity of biodiversity: A biological perspective on economic valuation. Ecol. Econ. 120: 350-354. doi: 10.1016/j.ecolecon.2015.10.003.

Felsenstein J (2004). Inferring Phylogenies. Am. J. Hum. Genet. 74: 92-97.

Felsenstein J (1985). Confidence Limits on Phylogenies: An Approach Using the Bootstrap. Evolution 39:783-791

Furlanetto C, Dianese JC (1999) Some Pseudocercospora species and a new Prathigada species from the Brazilian cerrado. Mycological Res. 103: 1203-1209. doi: 10.1017/S0953756299008394.

Hall BG (2011). Phylogenetic trees made easy: a how-to manual, 4 th. Sinauer Associates.

Hart MM, Aleklett K, Chagnon P, et al. (2015). Navigating the labyrinth: a guide to sequence-based, community ecology of arbuscular mycorrhizal fungi. New Phytol. 207: 235-247. doi: 10.1111/nph.13340.

Kumar S, Stecher G, Tamura K (2016) MEGA7: Molecular Evolutionary Genetics Analysis Version 7.0 for Bigger Datasets. Mol Biol Evol 33:1870-1874. doi: 10.1093/molbev/msw054

Lindahl BD, Nilsson RH, Tedersoo L, et al. (2013). Fungal community analysis by high-throughput sequencing of amplified markers - a user's guide. New Phytol. 199: 288-299. doi: 10.1111/nph.12243.

Miller GL (1959). Use of Dinitrosalicylic Acid Reagent for Determination of Reducing Sugar. Anal. Chem. 31: 426-428. doi: $10.1021 / \mathrm{ac} 60147 \mathrm{a} 030$.

Neiroti E and Azevedo IL (1988). Técnicas semiquantitativas de avaliação de produção de celulase em Humicola sp. Nat. Rev. Microbiol. 19: 78-81.

Ney M and Kumar S (2000). Molecular Evolution and Phylogenetics, Oxford Uni. New York.

Pandey AK, Reddy MS and Suryanarayanan TS (2003). ITS-RFLP and ITS sequence analysis of a foliar endophytic Phyllosticta from different tropical trees. Mycol. Res. 107: 439-444. doi: 10.1017/S0953756203007494.

Parreira DF, Silva M and Barreto RW (2014). Cercosporoid hyphomycetes associated with Tibouchina herbacea (Melastomataceae) in Brazil. Mycol. Progress. 13: 691-702. doi: 10.1007/s11557-013-0952-0.

Richards TA and Talbot NJ (2013). Horizontal gene transfer in osmotrophs: playing with public goods. Nat. Rev. Microbiol. 11: 720-727. doi: 10.1038/nrmicro3108. 
Ruegger MJS and Tauk-Tornisielo SM (2004). Atividade da celulase de fungos isolados do solo da Estação Ecológica de Juréia-Itatins, São Paulo, Brasil. Rev. Bras. Bot. 27: 205-211. doi: 10.1590/S0100-84042004000200001.

Saitou N and Nei M (1987). The neighbor-joining method: A new method for reconstructing phylogenetic trees. Mol. Biol. Evol. 4: 406-425.

Sanger F, Nicklen S and Coulson R (1977). DNA sequencing with chain-terminating inhibitors. Proc. Natl. Acad. Sci. USA. 74: 5463-5467. doi: 10.1093/annonc/mdp039.

Silva M, Barreto RW, Pereira OL, et al. (2016). Exploring fungal mega-diversity: Pseudocercospora from Brazil Persoonia. 37: 142-172. doi: 10.3767/003158516X691078.

Valencia EY and Chambergo FS (2013). Mini-review: Brazilian fungi diversity for biomass degradation. Fungal Genet Biol. 60: 9-18. doi: 10.1016/j.fgb.2013.07.005.

Warcup JH (1950). The Soil-Plate Method for Isolation of Fungi from Soil. Nature. 165: 150-151. doi: $10.1038 / 166117 \mathrm{~b} 0$.

White TJ, Bruns T, Lee S and Taylor J (1990). Amplification and direct sequencing of fungal ribosomal RNA genes for phylogenetics. In: Innis, M.A., Gelfand, D.H., Sninsky, J.J. and White, T.J., Eds., PCR Protocols: A Guide to Methods and Applications, Academic Press, New York, 315-322.

Wiseman A (1975). Handbook of Enzyme Biotechnology. Halsted Press.

Xu P, Han Y, Wu J, et al. (2007). Phylogenetic Analysis of the Sequences of rDNA Internal Transcribed Spacer (ITS) of Phytophthora sojae. J. Genet. Genomics. 34: 180-188. doi: 10.1016/S1673-8527(07)60019-8.

Zuckerkandl E and Pauling L (1965). Evolutionary Divergence and Convergence in Proteins. In: Bryson, V. and Vogel, H.J., Eds., Evolving Genes and Proteins, Academic Press, New York, 97-166. 